Dhaka Univ. J. Biol. Sci. 22(1): 1-7, 2013 (January)

\title{
TOXICITY OF SODIUM FLUORIDE (NaF) TO JUVENILE CATFISH, CLARIAS BATRACHUS
}

\author{
Shafina Shawon Sharmin, Md. Baki Billah*, Md. Kawser Ahmed ${ }^{1}$ \\ and Md. AbDus Salam \\ Department of Zoology, Jahangirnagar University, Dhaka-1342, Bangladesh
}

Key words: Sodium fluoride, Histopathology, Juvenile catfish, Toxicity

\begin{abstract}
Effects of sodium fluoride $(\mathrm{NaF})$ on Clarias batrachus in the aquarium at a sub lethal dose of $0,15,30,40,50$ and $60 \mathrm{mg} /$ for a chronic exposure period of 120 days were evaluated. The histopathological alterations in different tissues from brain, gill and liver were examined in fishes showed abnormal behaviors. Such as rupture of hepatocytes, congestion, necrosis pyknosis, cellular infiltration, and degenerative changes. In case of liver, individualization of hepetocytes, mild necrosis, vacuolation, pyknosis and hemorrhage were observed. These results suggest that $\mathrm{NaF}$ affects severely on the tissues of the internal organs leading to threat of life and survival.
\end{abstract}

\section{Introduction}

Sodium fluoride $(\mathrm{NaF})$ is an active ingredient of pesticide. It is a common pesticide used by farmers for the control of larvae and crawling insect in bars, warehouse and other storage area ${ }^{(1)}$. It is odorless, colorless to white a solid which readily dissolved in water (solubility 4.13/100 g). Fluoride level in freshwater generally ranges from 0.01 to 0.3 $\mathrm{mg} \lambda^{(2)}$. NaF is one of the biggest threats to the aquatic ecosystem when it enters by runoff and other illegal uses. There is, therefore the need to determine the tolerance limit of fish to NaF. Widespread use of herbicides and pesticides in agriculture and forestry is now a world-wide phenomenon(3). In Bangladesh, use of conventional insecticides and fertilizers are increasing day by day to increase crop productivity for the growing population within the limited agricultural lands. Though they enhance crop productivity, but in recent years, awareness about the potential harmful effects of the residues on human health has been growing and its contribution to the gradual degradation of the aquatic ecosystem cannot be ignored(4).

Pesticides and herbicides at high concentrations are known to reduce the survival, growth and reproduction of fish and produce many visible effects on fish ${ }^{(4)}$. Therefore, in view of this end the present study was undertaken to determine the behavioural pattern and body coloration exposed to $\mathrm{NaF}$ and to examine histopathological effects of $\mathrm{NaF}$ on organs (brain, gill and liver) of Clarias batrachus juveniles.

*Author for correspondence: <billah_z@yahoo.com>. ${ }^{1}$ Department of Fisheries, University of Dhaka, Dhaka-1000, Bangladesh. 


\section{Materials and Methods}

Healthy living specimens $(\mathrm{n}=200)$ of adult catfish, Clarias batrachus, with average length of $15 \pm 0.5$ and weight $20 \pm 0.5$ g were brought from Savar Bazar, Dhaka to the Fisheries and Limnology Laboratory in the Department of Zoology, Jahangirnagar University, where the experiment was conducted. Sodium fluoride $(\mathrm{NaF})$ was supplied by VWR International Ltd., England.

Glass aquaria $(60 \times 30 \times 30 \mathrm{~cm})$ used for acclimatizing the collected fish. The fish were acclimatized for seven days. In addition to $0 \mathrm{mg} /$ control, $\mathrm{NaF}$ concentrations of 15,30 , 40,50 and $60 \mathrm{mg} \Lambda$ doses were used to assess their effect on the growth and tissues of Clarias batrachus. Three replications were recorded for each concentration and also for the controls. The medium was mixed well after the addition of $\mathrm{NaF}$, and ten juvenile catfish were introduced into each aquarium. The exposure period was 120 days for all the concentrations including the controls. Fishes were treated by the method as described by Chakraborti et al. (2) and Omitogin et al.(5). The experiment was carried out in laboratory at room temperature of $28.1^{\circ} \mathrm{C}$ and $\mathrm{pH} 6.0-7.0$, respectively.

The behavioral pattern of the fish and other external changes in the body of the fish were observed accordingly. Water was changed regularly.

During the research period fishes were fed cattle livers once a day. To fullfill all the nutritional requirements, they were fed commercial fish food (perfect companion group Co. Ltd., Malaysia) once each day.

From the beginning to the end of the study period, dead fishes were quickly removed and mortality was recorded. Water quality parameters such as temperature and $\mathrm{pH}$ were measured using standard method( ${ }^{(6)}$.

After 120 days of $\mathrm{NaF}$ exposure fishes were collected from each aquarium, anesthetized with chloroform. Liver, brain and gills in each group were dissected out and preserved for histological analysis. The histological slides were prepared by the method developed by Luma ${ }^{(7)}$.

Photomicrography of the histological slides was done by using a microscope with photographic attachment (Olympus, Japan, $\mathrm{CH} 4 \mathrm{O}$ ) and camera (Olympus, Japan).

\section{Results and Discussion}

The effects of different concentrations and exposure time of $\mathrm{NaF}$ on Clarias batrachus juveniles are presented in Table 1. Results show that there was no mortality of fish in the control and those exposed to 15, 30 and $40 \mathrm{mg} \Lambda \mathrm{NaF}$ throughout 120 days. However, at $50 \mathrm{mg} /$ there was $50 \%$ mortality while at $60 \mathrm{mg} / 100 \%$ mortality were observed (Table $1)$.

The behaviour of the control fish was normal. Immediately the NaF was introduced into the test fish in different aquaria at different concentration levels, abnormal 
behaviour such as erratic swimming, restlessness, sudden quick movement, excessive secretion of mucus, rolling movements, swimming on the back (at higher concentrations) were observed. The fish became very weak, settled at the bottom and died in increasing numbers at $60 \mathrm{mg} /$. There was discoloration on the body of the fish at high concentrations. Normal color and behavioural responses were observed in the control. However, the color became pale progressively at higher concentrations at the end of 120 days.

Table 1. Histopahological change observed in the brain, gill and liver of Clarias batrachus juveniles subjected to different concentrations of $\mathrm{NaF}$ for 120 days.

\begin{tabular}{|c|c|c|c|c|c|c|c|c|}
\hline $\begin{array}{l}\text { Treatment } \\
(\mathrm{mg} /)\end{array}$ & Days & Organs & $\begin{array}{c}\text { Conges- } \\
\text { tion }\end{array}$ & Necrosis & $\begin{array}{c}\text { Cellular } \\
\text { infiltration }\end{array}$ & Lesions & Pyknosis & Hemorrhage \\
\hline 0 & 120 & B & - & - & - & - & - & - \\
\hline \multirow[t]{2}{*}{ (Control) } & & G & - & - & - & - & - & - \\
\hline & & $\mathrm{L}$ & - & - & - & - & - & - \\
\hline \multirow[t]{3}{*}{15} & 120 & B & + & - & - & - & - & - \\
\hline & & G & - & + & + & - & - & - \\
\hline & & $\mathrm{L}$ & + & 0.5 & - & - & - & + \\
\hline \multirow[t]{3}{*}{30} & 120 & B & - & - & - & - & - & - \\
\hline & & G & - & + & + & + & - & - \\
\hline & & $\mathrm{L}$ & H & - & - & - & + & + \\
\hline \multirow[t]{3}{*}{40} & 120 & B & + & - & - & - & - & ++ \\
\hline & & G & - & 0.5 & - & + & - & - \\
\hline & & $\mathrm{L}$ & + & + & + & - & + & + \\
\hline \multirow[t]{3}{*}{50} & 120 & B & H & - & - & - & - & ++ \\
\hline & & G & - & H & + & + & - & - \\
\hline & & $\mathrm{L}$ & H & H & - & + & H & ++ \\
\hline \multirow[t]{3}{*}{60} & 120 & B & H & - & + & - & H & ++ \\
\hline & & G & - & + & + & - & - & ++ \\
\hline & & L & H & + & 0.5 & + & H & ++ \\
\hline
\end{tabular}

B = Brain, G = Gill, L = Liver, - = Completely absent,$+=$ Present, 0.5 = Mild, ++ = Severe. Treatment with negative signs indicated no histopathological changes were observed.

The histopathological observation showed that there were changes in color on the brain of fish exposed to different concentrations of $\mathrm{NaF}$, while there were no lesions found in the brain of fish in the control (Fig. 1a). Fish exposed to concentration $15 \mathrm{mg} A$ $\mathrm{NaF}$ (Fig. 1b) showed mononuclear infiltration whereas fish exposed to concentrations of 50 and $60 \mathrm{mg} /$ showed severe brain damage (Fig. 1c, d).

The gill of the control experimental fish was normal (Fig. 2a) while at different concentrations of $\mathrm{NaF}$, there was swollen tip of the gill filament. However, at $60 \mathrm{mg} \Lambda$, the gill was severely damaged (Fig. 2d) and congestion was severe at 30, 40 and $50 \mathrm{mg} /$ while sub mucosa necrosis was observed at $15 \mathrm{mg} /$ during the study period (Fig. $2 b, c$ ). 
The liver of fish in the control was normal without necrosis (Fig. 3a). Hepatocytes and other cells were normal and systematically arranged.

There was mild necrosis and minor vacuolation at the concentration of $15 \mathrm{mg} \Lambda$, hypertrophy of hepatocytes was also observed (Fig. 3b), at 50 and $60 \mathrm{mg} /$, severe necrotic hepatocytes, pyknosis, hypertrophy, haemorrhage and vacuolation were observed accordingly as described in Fig. 3c, d.
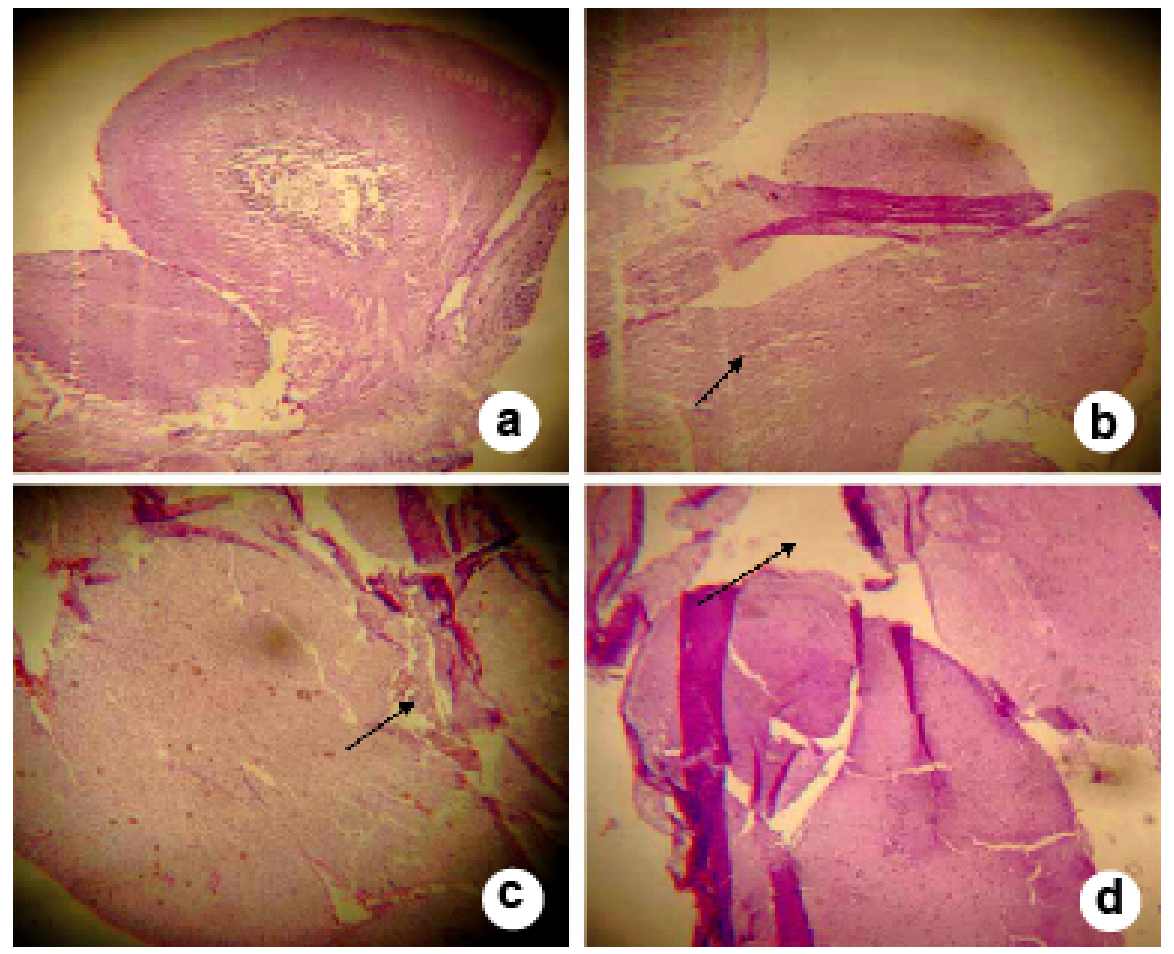

Fig. 1a-d. (a) Brain of Clarias batrachus exposed in control group no significant lesion seen. (b) Brain of Clarias batrachus to $15 \mathrm{mg} / \mathrm{NaF}$ showing mononuclear infiltration. (c) Brain of Clarias batrachus exposed to $50 \mathrm{mg} / \mathrm{NaF}$ showing severe brain damage. (d) Brain of Clarias batrachus exposed to $60 \mathrm{mg} / \mathrm{NaF}$ showing severe brain damage.

The NaF exerted toxic effect on the fish in the present study. However, the toxicity of pesticides on different species of fishes have been reported and the present findings agreed with ${ }^{(8,9)}$. Accumulation of mucus in the gills of fish exposed to the different concentrations of $\mathrm{NaF}$ in this study might be responsible for the mortality recorded. Konar ${ }^{(10)}$ reported that accumulation of mucus on the gills reduces respiratory activity in fish. The inability of the gill surface to actively carry out gaseous exchange might be responsible for the observed mortalities ${ }^{(11)}$. 
Several abnormal behavior such as incessant jumping and gulping of air, restlessness, loss of equilibrium, increase of opercular activities, surface to bottom movement, sudden quick movement, resting at the bottom were similar to the observations of ${ }^{(1)}$, and ${ }^{(12)}$. Swelling in the abdominal region and gas filled stomach were not observed, which is contrary to the findings of ${ }^{(13)}$ and this is an indication that the effect of pesticides and herbicides are species specific ${ }^{(1)}$. Water quality parameters measured seem to be within optimum range for fish culture as reported by Fafioye $e t$ al. (2004)(14). Temperature, $\mathrm{pH}$, sex, age and other physiological status of the test animals have profound effects on the toxicity of agro chemicals(2). Meletev et al. ${ }^{(15)}$ reported that pesticides affect the gas exchange of fish and other aquatic organisms.

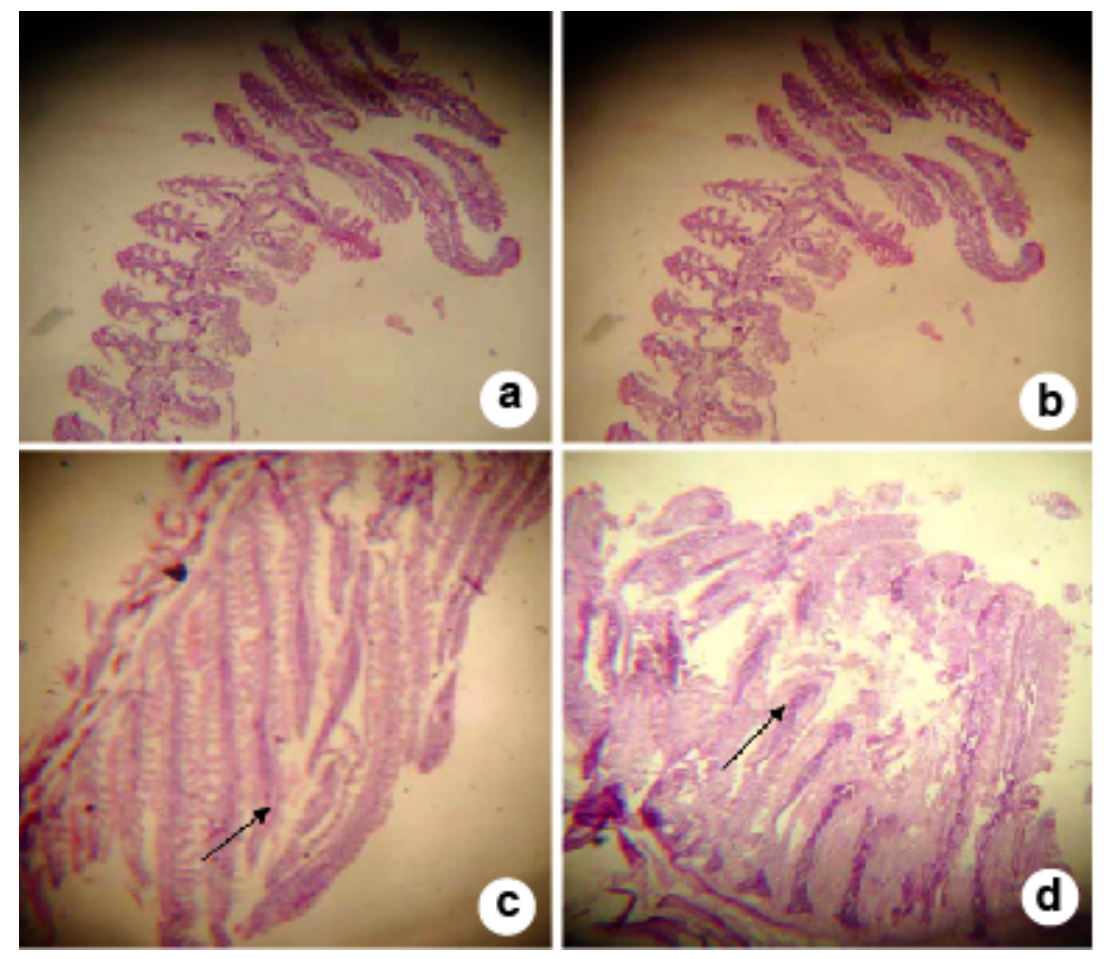

Fig. 2a-d. (a) Gill of Clarias batrachus exposed to control group showed no significant lesion. (b) Gill exposed to $15 \mathrm{mg} / \mathrm{NaF}$ showing necrosis. (c) Gill exposed to $50 \mathrm{mg} / \mathrm{NaF}$ showing swollen tip of gill filament. (d) Gill exposed to $60 \mathrm{mg} \Lambda \mathrm{NaF}$ showing severe damage.

At the agricultural dose of $1.13 \mathrm{ppm}$ of diazinon $60 \mathrm{EC}$, mild pyktonic and necrotic hepatocytes, hypertrophy and in a few cases vacuolation were observed on all the fish species $^{(1)}$. However, at the highest concentration of $60 \mathrm{mg} /$ of NaF severe degenerative changes such as necrosis, pyknosis, vacuolation, rupture of blood vessel causing hemorrhage were observed and this agreed with findings of Omitoyin et al. (1999)(5). Severe brain damage was observed in fish exposed to $60 \mathrm{mg} A$ of the herbicide and there 
was mononuclear cellular infiltration of the cerebral meninges and neuronal degeneration.

At $30 \mathrm{mg} /$ of $\mathrm{NaF}$ exposure to Clarias batrachus there was more severe lesion than at $15 \mathrm{mg}$ /. There was moderate vascular congestion in the sub mucosa lamina propriae 15 $\mathrm{mg} /$ while 50 and $60 \mathrm{mg} /$ showed diffuse infiltration of villi lamina propriae by monuclear cells as observed by Omitoyin et al. (1999)(5).
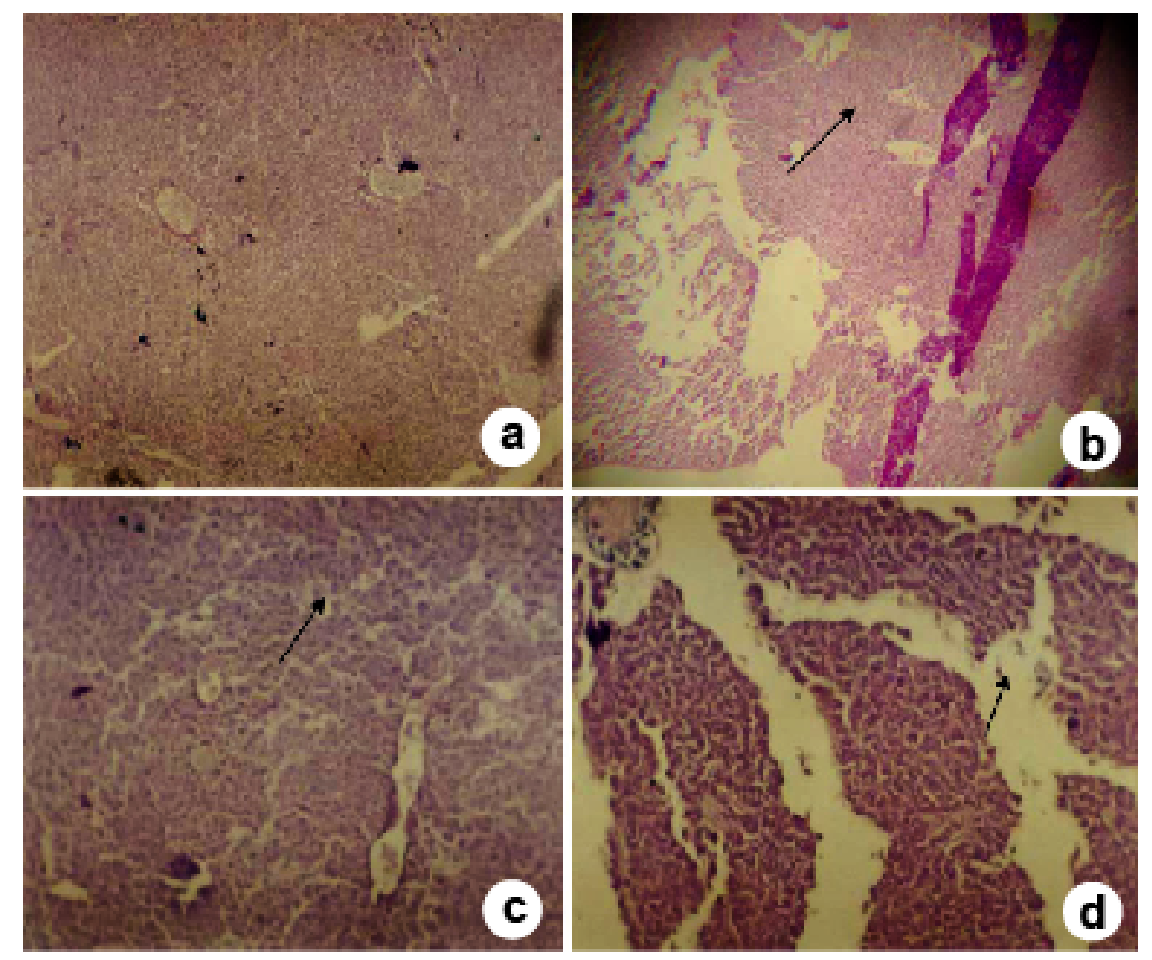

Fig. 3a-d. (a) Liver of Clarias batrachus exposed to control showing no necrosis. (b) Liver exposed to $15 \mathrm{mg} / \mathrm{NaF}$ showing of hepatocytes. (c) Liver exposed to $50 \mathrm{mg} / \mathrm{NaF}$ showing vaculation and picnosis. (d) Liver exposed to $60 \mathrm{mg} / \mathrm{NaF}$ showing diffuse hepatic necrosis and vaculation.

The results of the present study revealed that $\mathrm{NaF}$ is toxic to fish organs. The consequences of the pesticide application in paddy field play havoc to the non-target fish species. Thus, fish is one of the most important experimental aliquots for studying toxicity effects. However, the study was conducted to evaluate the effects of $\mathrm{NaF}$ on the different tissues of Clarias batrachus. Therefore, indiscriminate use of NaF by farmers should be discouraged particularly in an area close to aquatic environment. 


\section{References}

1. Rahman MZ, Z Hossain, MFA Mollah and GU Ahmed 2002. Effect of diazmon 60 EC on Anabas testudineus, Channa punctatus and Barbodes gonionotus Naga. The ICLARM Quarterly 25: 8-11.

2. Camargo JA 2003. Fluoride toxicity to aquatic organisms: A review. Chemosphere 50(3): 25164.

3. Sandipan P Chakraborti, Mukherjee AK and Ghosh AR 2007. Histopathological and ultra microscopical altrations induced by sodium fluoride in the different tissues of an airbreathing teleost, Channa punctatus (Bloch); Inter. Conf. on Ecotoxi. and Envi. Sci. contribuated papers p. 43.

4. Ahmed M and A Moitra 1990. Microanatomical and histopathological changes in the intestine of Catla catla exposed to cupper sulphate. J. Freshwat. Biol. 2(3): 241-249.

5. Omitoyin BO, AO Ogunsanmi and BT Adesina 1999. Studies on actuate toxicity of piscicidal plant extracts (Tetrapleura tetrapterd) on tilapia (Sarotherodon galilaeus) fingerlings. Trop. J. Anim. Sci. 2: 91-97.

6. APHA 1998. Standard methods for the examination of water and waste water, 20th Edn, American Public Health Association, New York, USA., 1076 Rev. Ed.

7. Luna LG 1968. Manual of histologic straining methods of the armed forces Institute of Pathology McGraw-Hill book Co., New York, USA.

8. Cakmak MN and A Girigin 2003. Toxic effect of a synthetic pyrethroid insecticide (cypermethrin) on blood cells of Rainbow Trout (Oncorhynchus mykiss, Walbaum). J. Biol. Sci. 3: 694-698.

9. Edwards RP and Millbum D Hudson 1986. Comparative toxicology of cis-cypermethrin in rainbow trout, frog, mouse and quail. Toxicol. Applied Pharmacol. 84: 512-522.

10. Konar S.K 1975. Pesticides and aquatic ecosystems. Indian J. Fish 22: 80-85.

11. Omoniyi LA, O Agbon and SA Sodunke 2002. Effect of lethal and sub-lethal concentrations of Tobacco (Nicotiana tabaccum). Leaf dust extraction on weight and Haemetaological changes in Glorias gariepinus (Burchell). J. Applied Sci. Environ. Man. 6: 37-41.

12. Lovely F 1998. Toxicity of three commonly used organo-phosphorus insecticides to Thai sharputi (Barbodes gonionotus) and African catfish (Glorias gariepinus) Fry. Department of Fisheries Biology and Generics, Bangladesh Agricultural University, Mymensigh, Bangladesh, M.Sc. Thesis. pp. 83.

13. Kabir SMH and R Begum 1978. Toxicity of three organophosphorus insecticides to singhi fish, Heteropneustes fossils (Bloch). Dhaka Univ. Studies 26: 115-122.

14. Fafioye O, AA Adebisi and SO Fagade 2004. Toxicity of Parkia biglobosa and Rephia vinifera extracts on Claria gariepinus Juveniles. African J. Biotechnol. 3: 627-630.

15. Meletev VV, AS Kanaev and NG Dzasokhova 1971. Water toxicology. American Publishing Co. Put. Ltd. pp. 216. 